\title{
PENGEMBANGAN JAGUNG TAHAN KERING UNTUK PENINGKATAN PENDAPATAN ANGGOTA SUBAK DI KECAMATAN SELEMADEG TIMUR KABUPATEN TABANAN
}

\author{
I.G.P. Ratna Adi ${ }^{1}$, I.K. Sardiana ${ }^{1}$, dan N.W. Siti ${ }^{2}$ dan I.N. Ardika ${ }^{2}$
}

\begin{abstract}
ABSTRAK
Pendapatan petani lahan sawah di Subak Aseman Desa tangguntiti masih rendah karena kesulitan air irigasi dan harga panen padi yang relatif masih rendah dan fluktuatif. Pengembanan usaha tani baru yang lebih menguntungkan perlu dirintis untuk meningkatkan pendapatan petani tersebut. Kegiatan pengabdian masyarakat ini bertujuan untuk meningkatkan pendapatan petani lahan sawah melalui agribisnis benih jagung tahan kering. Metode yang diterapkan adalah bimbingan teknis dan pendampingan tenik penangkaran benih jagung, teknik pengemasan dan pemasaran. Hasil pengabdian menunjukkan bahwa usaha produsen benih jagung cocok diterapkan sebagai usaha tani di subak aseman dalam mengantisipasi kekurangan air irigasi. Hasil analisis usaha tani menunjukkan bahwa usaha produsen benih jagung mampu memberikan keuntungan $47 \%$.
\end{abstract}

Kata kunci : subak, usaha tani, produsen benih jagung, peningkatan, pendapatan.

\begin{abstract}
The income of paddy farmers in Subak Aseman Desa Tangguntiti is still low due to irrigation water shortages and relatively low and volatile rice harvest prices. The development of new, more profitable farms needs to be initiated to increase the income of these farmers. This community service activity aims to increase the income of farmers in paddy fields through dry-corn corn agribusiness. The method applied is technical guidance and technical assistance for corn seed breeding, packaging and marketing techniques. The results of the dedication show that the corn seed producer business is suitable to be applied as a farming business in Subak Aseman in anticipating irrigation water shortages. The results of the analysis of farming shows that corn seed producer businesses can increase income by $200 \%$..
\end{abstract}

Keywords: subak, farming, corn seed producers, increase, income.

\section{PENDAhuluan}

Desa Tangguntiti termasuk ke dalam wilayah Kecamatan Selemadeg Timur Kabupaten Tabanan, berada pada ketinggian antara 100 - $450 \mathrm{~m}$ dpl dengan luas wilayah 1760,384 ha. Penggunaan lahan di wilayah ini utamanya untuk lahan persawahan 1266,692 ha $(71,96 \%)$, diikuti lahan tegal/kebun 422,232 ha $(23,99 \%)$, pekarangan 51,8 ha $(2,94 \%)$, dan lain-lain 19,66 ha $(1,12 \%)$. Wilayah ini dikenal sebagai sentra penghasil padi dan lumbung beras bagi Kabupaten Tabanan. Keberhasilan usaha tani padi di daerah ini sangat menentukan ketersediaan dan harga beras di Kabupaten Tabanan.

\footnotetext{
${ }^{1}$ Program Studi Agroekoteknologi Fakultas Pertanian Universitas Udayana, ratnaadi@unud.ac.id

${ }^{2}$ Program Studi Peternakan Fakultas Peternakan Universitas Udayana, wyansiti@unud.ac.id
} 
Produk unggulan pada sector pertanian dari wilayah ini adalah padi. Produksi beras Tangguntiti sangat dikenal di Bali karena rasanya yang pulen dan memegang peran yang sangat penting bagi ketersediaan beras di kabupaten Tabanan. Petani padi di wilayah ini, seperti juga halnya dengan pertanian lahan sawah di tempat lainnya di Bali tergabung dalam organisasi yang disebut subak. Subak adalah organisasi petani yang bersifat sosio-religus dengan fungsi utama mengatur tatapemanfaatan air irigasi. Di Desa tangguntiti terdapat 4 subak yaitu subak aseman 1, aseman 2, aseman 3, dan lanyah dengan jumlah anggota mencapai 658 orang petani. Namun demikian, lahan sawah yang begitu luas tidak didukung oleh ketersediaan air yang memadai. Akibat kurangnya pasokan air irigasi tersebut petani hanya bisa melakukan penanaman pati sekali setahun. Bahkan pada lima tahun terakhir, sistem pengairan lahan sawah sudah seperti sawah tadah hujan sehingga waktu tanaman sangat tergantung kepada air hujan.

Dalam rangka meningkatkan pendapatan petani lahan sawah di daerah ini perlu dilakukan upaya pengembangan pertanian yang tidak sepenuhnya tergantung kepada tersediaan air irigasi atau dengan kata lain toleran terhadap kekurangan air. Salah satu peluang yang potensial dikembangkan adalah melalui usaha penangkaran jagung tahan kering.

Jagung tahan kering adalah varietas jagung yang toleran tehadapa kekurangan air. Jagung ini merupakan hasil penelitian peneliti Fakultas Pertanian Universitas Udayana hasil dari pemuliaan jagung lokal yang toleran tumbuh di daerah kering seperti daerah Grokgak Kabupaten Buleleng dan Kubu Karangasem. Keunggulan jagung ini dari varietas asalnya adalah tongkol buah yang lebih besar, tetapi sifat toleran terhadap kekeringan tetap dipertahankan. potensi produksinya cukup tinggi (sekitar $5 \mathrm{t} / \mathrm{ha}$ ). Buah jagung muda terasa enak dan memiliki tekstur kenyal sehingga cocok dipanen muda untuk dijadikan jagung rebus sehingga saat panen biomasanya masih hijau (stay green) sehingga dapat dimanfaatkan sebagai pakan ternak (sapi) yang baik.

Produk benih ini memiliki peluang pasar yang sangat besar mengingat luas lahan kering di Indonesia cukup luas. Sebagai contoh untuk Propinsi Bali, potensi lahan untuk usaha tani jagung mencapai 480.559 hektar. Bila diasumsikan bahwa kebutuhan benih jagung per hektar rata-rata $25-30 \mathrm{~kg} / \mathrm{ha}$, maka benih yang diperlukan sebanyak $1.216,77$ ton per tahun. Kebutuhan ini masih jauh di bawah kebutuhan benih jagung untuk Propinsi NTB dan NTT yang memliki luas lahan kering yang sangat luas.

Kegiatan pengabdian kepada masyarakat ini bertujuan untuk meningkatkan pendapatan petani lahan sawah yang tergabung dalam organisasi Subak melalui keterampilan dalam penangkaran benih sehingga mampu menjadi petani produsen benih jagung yang mandiri.

\section{METODE PELAKSANAAN}

Metode yang diterapkan dalam kegiatan pengabdian kepada masyarakat ini dilakukan melalui beberapa pendekatan, yaitu: (1) Partisipatory Rural Appraisal (PRA), yaitu dengan melibatkan masyarakat dalam berbagai aspek mulai dari perencanaan, pelaksanaaan hingga evaluasi; (2) model Entrepreneurship Capacity Building (ECB), yaitu meningkatkan kapasitas masyarakat berwirausaha; dan (4) model Teknologi Transfer (TT), yaitu aplikasi teknologi tepat guna.

Kegiatan dilakaukan melalui beberapa tahapan, yaitu :

(1) Sosialisasi dan berbagi pengalaman dengan kelompok tani Mekar Setya Bakti, Desa Tangguntiti, Kecamatan Selemadeg Kabupaten Tabanan

(2) Bimbingan teknis teknik penangkaran benih jagung tahan kering

(3) Pembuatan Denplot Budidaya Jagung tahan kering

(4) Teknik panen dan penanganan pasca panen 
(5) Analisis usaha

\section{HASIL DAN PEMBAHASAN}

Pelaksanaan kegiatan Pengabdian kepada Masyarakat di kedua mitra dapat berjalan dengan baik dan dengan peran serta mitra yang cukup tinggi (Tabel 3.1), dimana kegiatan penyuluhan dan pelatihan singkat yang diikuti oleh $100 \%$ anggota mitra dan pada kegiatan tersebut 53,3\% anggota mitra telah memahami pentingnya usaha penangkaran benih sebagai usaha potensial untuk meningkatkan pendapatan petani, serta sebanyak $40 \%$ peserta talah memahami tahapan proses penangkaran benih.

Tabel 3.1. Partisipasi Mitra dalam Kegiatan

\begin{tabular}{|c|c|c|c|}
\hline \multirow{2}{*}{ No } & \multirow{2}{*}{ Kegiatan } & \multicolumn{2}{|c|}{ Mitra I } \\
\hline & & Jumlah & $\%$ \\
\hline A & Kegiatan Penyuluhan - Pelatihan Singkat & & \\
\hline 1 & Absensi/Kehadiran & 20 & 100 \\
\hline 2 & Faham arti penting usah produsen benih & 10 & 53,3 \\
\hline 3 & Memahami tahapan penangkaran benih & 8 & 40 \\
\hline $\mathrm{B}$ & Kegiatan Demoplot & & \\
\hline 1 & Membantu proses pembuatan demplot & 20 & 100 \\
\hline 2 & Aktif hadir dan diskusi pada penerapan SOP & 14 & 73,3 \\
\hline 3 & Dapat melakukan panen dengan baik & 11 & 55 \\
\hline 4 & Melakukan pasca panen (grading dan pengemasan) & 8 & 40 \\
\hline 5 & Melakukan analisis usaha & 4 & 30 \\
\hline
\end{tabular}

Begitu juga dengan kegiatan pembuatan Demoplot mendapatkan partisipasi yang tinggi dari peserta $(100 \%)$, dan yang aktif mengunjungi demplot sebanyak $73,3 \%$. Sementara peserta yang dapat menentukan waktu panen dan teknik panen dengan baik sebanyak 55\%, penanganan pascapanen sebanyak $40 \%$, serta mampu melakukan analisis usaha sebanyak $20 \%$.

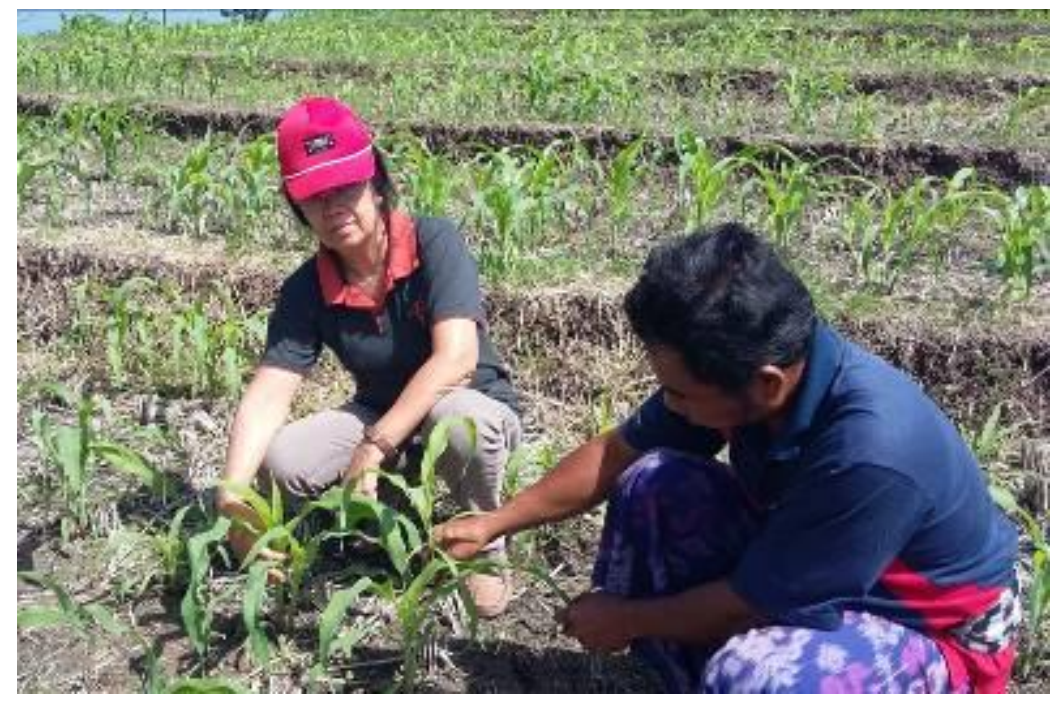

Gambar 3.1. Penanaman Jagung Tahan Kekeringan (Sumber : koleksi pribadi)

Dari hasil Bimtek prosedur penangkaran benih diperoleh pemahaman bahawa, ada beberapa 
tahapan yang harus dilakukan oleh petani penangkar benih jagung, yaitu :

(1) petani membuat daftar kebutuhan sarana dan prasarana produksi dan prosesing benih

(2) musyawarah dengan anggota kelompok tani/Subak untuk mendata luas areal tanam jagung.

(3) Menentukan calon konsumen/pasar dengan harga yang telah disepakati bersama.

(4) melaksanakan produksi benih jagung dengan memerhatikan isolasi waktu dan jarak serta teknik produksi yang baku.

(5) kontrol kualitas dengan menjalankan seluruh tahapan dan prosedur sertifikasi benih.

(6) Melakukan kontrol kualitas dalam proses produksi dengan melaksanakan detaselling dan roughing tepat waktu.

(7) kontrol kualitas saat panen dan pasca panen dengan melakukan prosesing benih dan pengeringan hingga mencapai kadar air yang aman untuk penyimpanan benih

(8) Pengemasan yang kedap dan rapih (sesuai standar pengemasan dan pelabelan).

Analisa Usahatani

Hasil analisa usahatani budidaya jagung tahan kering (varietas Cicih Tombong) memperlihatkan bahwa pada luas garapan rata-rata dari petani binaan 0.40 ha dapat menghasilkan produksi pipilan sebanyak 4,62 t/ha. Hasil produksi tersebut dijual pada harga $\mathrm{Rp} .3 .000,-/ \mathrm{kg}$ dengan total nilai produksi sebesar Rp. 5,754,212,-. Nilai produksi tersebut masih akan dikurangi oleh biaya-biaya yang antara lain adalah a) biaya untuk benih Rp, 359,648. b) biaya untuk pupuk Rp. 548,036,-, c) biaya untuk pestisida Rp. 140,808, d) biaya tenaga kerja sebesar Rp. 1,980,452,-. Total biaya yang harus dikeluarkan selama musim tanam adalah Rp. 4,078,856, keuntungan yang diperoleh tiap-tiap petani adalah 1,675,356,-. Nisbah keuntungan/biaya dari usaha-tani tersebut adalah 1,47. Ini artinya bahwa usahatani jagung tahan kering sangat menguntung

\section{KESIMPULAN}

Berdasarkan pembahasan di atas, maka dapat disimpulkan sebagai berikut:

(1) Peserta pengabdian masyarakat memberikan partisipasi yang cukup tinggi yaitu tingkat kehadiran mencapai $100 \%$ anggota mitra, $53,3 \%$ peserta memahami pentingnya usaha penangkaran benih sebagai usaha potensial untuk meningkatkan pendapatan petani, serta sebanyak $40 \%$ peserta talah memahami tahapan proses penangkaran benih.

(2) Sebanyak 73,3\% memahami SOP penangkaran benih jagung, mempraktekan teknik panen dengan baik sebanyak 55\%, pascapanen sebanyak 40\%, serta analisis usaha sebanyak $20 \%$.

(3) Usahatani jagung tahan kering sangat menguntung dengan $\mathrm{B} / \mathrm{C}$ rasio 1,47.

\section{UCAPAN TERIMA KASIH}

Tulisan ini merupakan hasil kegiatan Prgram Pengembangan Kemitraan Wilayah (PKW). Oleh sebab iu, Penulis menyampaikan terima kasih sebesar-besarnya kepada Direktorat Riset dan Pengabdian kepada Masyarakat Kemenristekdikti yang telah memberikan pembiayan pelaksanaan kegiatan PKW tersebut.

\section{DAFTAR PUSTAKA}

Sardiana, I.K., B.R.T. Putri, I.G. Suranjaya, N.L.R. Purnawan. 2015. Pengembangan Kewirausahaan Di Universitas Udayana. Majalah Aplikasi Ipteks Ngayah : Vol. 6, No. 1, pp. 91-101.

Ramlah Arief, R. dan M. T. Ratule. 2015. Strategi Penguatan Penangkaran Benih Jagung Berbasis Komunitas. Prosiding Seminar Nasional Serealia Nama Penulis (tahun), Judul Buku, Penerbit

BPS, 2017. Kecamatan Selemadeg Timur dalam Angka. Badan Pusat Statistik kabupaten Tabanan. Tabanan Bali. 